\title{
Platonismo para el pueblo, inmanencia y trascendencia en la teoría platónica de las ideas
}

Platonism for the masses, inmanence and trascendence in Plato's theory of ideas

\author{
Álvaro Vallejo Campos \\ Catedrático de Universidad, Departamento de Filosofía II, Universidad de Granada \\ avallejo@ugr.es
}

\author{
ATEÍSMO, CREENCIA Y SENTIDO. HOMENAJE A JUAN ANTONIO ESTRADA \\ MONOGRÁFICO COORDINADO POR REMEDIOS ÁVILA Y MIGUEL MORENO
}

\begin{abstract}
RESUMEN
En la lectura que Nietzsche hace de Platón, en torno al problema del nihilismo, distingue perfectamente entre el platonismo en sí y su recepción en el cristianismo. Uno de los puntos en que difieren radica en el carácter transmundano que la idea del "mundo verdadero" adquiere en el cristianismo. La teoría platónica de las ideas supone una ambigüedad consustancial entre inmanencia y trascendencia que no permite interpretarla ontológicamente como un dualismo de dos mundos separados, en el sentido más simple del chorismós aristotélico. El propio Platón utilizó una iconografía que propicia esta interpretación y a la vez la corrige, porque el motivo fundamental de la teoría del mundo ideal no era duplicar la realidad existente sino encontrarle el sentido que los presocráticos no supieron hallar en ella a la luz de una interpretación meramente mecanicista.
\end{abstract}

\section{ABSTRACT}

In Nietzsche's reading of Plato's philosophy, he distinguishes clearly in relation to nihilism between Plato and his reception in Christianity. One of the main points depends on the otherworldly character that the idea of the "true world" has in Christian thought. Plato's theory of ideas implies an essential ambiguity between immanence and transcendence that cannot be interpreted ontologically as a dualism of two separated worlds, as in the most simple sense of the Aristotelian chorismós. Nevertheless, Plato himself created an iconography which is favourable to this interpretation, although he corrects it at the same time, because the fundamental motive of the ideal world is not to duplicate this world, but to find that sense which the Presocratic philosophers were unable to explain in terms of a merely mechanistic theory of becoming.

PALABRAS CLAVE

Platón | Nietzsche | chorismós | dualismo | inmanencia | trascendencia | transmundanidad

KEYWORDS

Plato | Nietzsche | dualism | chorismos | immanence | transcendence | otherworldliness

\section{Introducción}

La expresión "platonismo para el pueblo" (Christenthum ist Platonismus für's Volk) procede, como es sabido de F. Nietzsche, que la utiliza en el Prólogo de Más allá del bien y del mal para definir así el cristianismo. Metafísica, platonismo y cristianismo constituyen para Nietzsche un pernicioso conglomerado de ideas, porque son los tres vértices de un triángulo que conduce al nihilismo. Los tres ingredientes a los que nos referimos han generado un dispositivo para la creación de sentido, pero, cuando se hunden sus fundamentos en el proceso histórico de la civilización occidental, sustraen el valor del mundo que le había sido otorgado a este con las categorías de la razón y "entonces el mundo parece carente de valor..." (Nietzsche 2006: 396, frag. 11 [99]). Sin embargo, decir que el cristianismo es platonismo para el pueblo significa rebajar la sutileza metafísica del pensamiento platónico y, desde luego, distinguirlo del cristianismo como dos formas semejantes, pero diferentes de la cultura europea. El hecho de que Nietzsche haya afirmado que Platón es "el puente que lleva a la cruz" (Nietzsche 1973: 131) no le impidió, efectivamente, ver las diferencias por las que no puede decirse que el platonismo sea sin más un equivalente del cristianismo. En el famoso capítulo titulado "Cómo el mundo verdadero acabó convirtiéndose en una fábula" del Crepúsculo de los ídolos, Nietzsche especifica seis etapas diferentes concebidas como una especie de cadena cuyo conjunto traza el arco que va desde la creación de la metafísica en Platón hasta la superación del nihilismo que se produce en el "instante de la sombra más corta", cuando se disipan con el advenimiento de Zaratustra las brumas que la caverna platónica había proyectado sobre el mundo aparente. Pero la metáfora de la cadena, que he utilizado para referirme con 
ella a la filosofía de la historia suscrita por Nietzsche (para la configuración del nihilismo como una filosofía de la historia universal, véase, por ejemplo, Fink 1979: 187, Deleuze 1971: 213 y Volpi 2004: 51), quiere hacer referencia a las semejanzas que permiten el engarce de un eslabón con otro, pero también a las diferencias por las que hay que añadir cada eslabón, ya que cada uno prolonga la cadena una etapa más allá que la anterior agregando un rasgo que no estaba en la etapa precedente. Precisamente esto es lo que ocurre con la diferencia entre Platón y el cristianismo. No hay duda de que Nietzsche atribuyó a Platón la metafísica del mundo verdadero, pero, al enumerar las etapas, él establece un contraste entre el platonismo y el cristianismo que no carece de importancia. En la primera etapa, inaugurada por Platón, que representa "la forma más antigua de la Idea", Nietzsche afirma que el mundo verdadero "es asequible al sabio", ya que, efectivamente, "él vive en ese mundo, es ese mundo" (Nietzsche 1971: 51). Sin embargo, cuando pasamos al siguiente eslabón en la evolución de la metafísica, el cristianismo convierte el mundo verdadero en "inasequible por ahora" y en algo que solo puede ser "prometido al sabio, al piadoso, al virtuoso y 'al pecador que hace penitencia”'. ¿Qué es lo que ha añadido el cristianismo a la metafísica del mundo verdadero creada por Platón? Ha convertido esa duplicidad en dos realidades tan separadas que no se puede transitar de la una a la otra, porque corresponden a dos momentos diferentes de la vida, terrenal y material, el uno, y sobrenatural e inmaterial, el otro.

Estamos tan acostumbrados a leer el platonismo desde la perspectiva transmundana aportada por el cristianismo que no percibimos esta diferencia que a Nietzsche no parece haberle pasado inadvertida. Muchas circunstancias influyeron en esta apropiación cristiana del platonismo y, desde luego, para empezar, la afirmación platónica de lo inteligible no era poca cosa para establecer ahí las bases sobre las que sujetar el siguiente eslabón de la transmundanidad. Los primeros pensadores cristianos comprendieron que muchas ideas platónicas o neoplatónicas eran muy próximas a su propia doctrina religiosa (véase el útil resumen de William A. Welton 2001: 1-2 sobre la tremenda influencia del platonismo en la teología cristiana). Esto no impidió que captaran las diferencias, porque para ellos se trataba de una doctrina que no estaba totalmente respaldada por la revelación divina. Pero de todas formas muchos coincidieron al considerar el platonismo el pensamiento filosófico más próximo a la fe cristiana. Sin embargo, el cristianismo añadió la transmundanidad con una claridad o, más aún, con una simplicidad que no estaba en los orígenes de la metafísica platónica. Esta no pretendía una duplicación de la realidad física, como si se tratara de crear un mundo virtual poblado por entidades de otro género y ajenas al mundo en el que vivimos. Sin embargo, la versión aristotélica de la teoría de las ideas como entidades separadas de otra naturaleza y la apropiación realizada por el cristianismo, que interpretó lo inteligible como una realidad sobrenatural, nos ha hecho olvidar a menudo el sentido original que tenía la metafísica platónica, ese sentido que deberíamos tener presente para no confundirla con el platonismo para el pueblo al que Nietzsche con razón se refiere. Este es el objetivo que me propongo afrontar en este artículo.

\section{La interpretación aristotélica de las ideas como entidades separadas}

Lo que he denominado transmundanidad, que es la tendencia a interpretar el mundo inteligible propuesto por Platón como un dualismo de dos niveles ontológicos separados e independientes, ha sido favorecida desde luego por el cristianismo, pero también, en primer lugar, por el mismo Platón, que utilizó unas expresiones que hablan claramente de una diferencia ontológica entre ambos niveles y empleó una iconografía dualista, a veces desorientadora, de las que nos ocuparemos más adelante. Pero esta interpretación se ha visto amparada también por la recepción de la teoría de las ideas en las obras de Aristóteles. Voy a comenzar por esta, porque creo que es la que mejor fija los términos de la llamada transmundanidad, que es lo que facilitó la interpretación del cristianismo en la terminología de Nietzsche como "platonismo para el pueblo". Chōrismós (separación) y sus derivados son los términos clave a través de los cuales Aristóteles interpretó la teoría de las ideas. Si no forjó él mismo este vocabulario, en el sentido técnico que tiene, como de hecho se ha sugerido, desde luego contribuyó a difundirlo en caso de que ya existiera su uso en la Academia (1). En su versión de la teoría platónica de las ideas, estas, efectivamente, son "entidades separadas" (oúoías xwpıotàs, Metaf. VII 14, 1039a25).

Ahora bien, Platón nunca aplica esta terminología a las ideas, lo cual no quiere decir que no considerara diferentes los dos niveles de realidad característicos del platonismo. Por un lado, están las entidades inmersas en el devenir, que para él son siempre imperfectas o carentes de una identidad absoluta, ya que admiten en su naturaleza lo que es contrario o diferente de su esencia. Por ello están a medio 
camino entre el ser y el no ser (cfr. Rep.478d-479d), además de estar sujetas al cambio y la transformación continuos. Es la realidad propia de la génesis. Por otro lado, Platón identifica con el ser verdadero o ousía (Rep. 479c7) el que corresponde a las formas o entidades ideales, que permanecen ajenas al cambio y son perfectas o idénticas a sí mismas, al no admitir en su naturaleza nada que sea contrario a su esencia. Es imposible negar en Platón la existencia de esta dualidad, porque pueden aducirse multitud de textos que la avalan desde el Fedón hasta el Timeo y otros diálogos tardíos (ara un repertorio de pasajes, me permito remitir al lector a Vallejo Campos 2017: 225-228).

Además, el intento de reducir las ideas, como procuró la interpretación neokantiana de Natorp, a meros correlatos gnoseológicos, al sostener que significan "objetos, pero no cosas", se estrella contra lo que dicen literalmente los textos. Es verdad que, en una especie de razonamiento trascendental, al estilo kantiano, la existencia de las dos clases de conocimiento establecidos por Platón, la opinión verdadera y la intelección, nos conduce a la distinción de los dos planos de la realidad. Pero esto no impide a Platón diferenciarlos desde un punto de visto ontológico con las expresiones más rotundas y explícitas que podamos exigir. En el Timeo, diferencia, tres niveles o géneros de realidad: las cosas generadas, las ideas a semejanza de las cuales se generan aquellas y el espacio o nodriza del devenir, que proporciona una sede que sirve de sustentación ontológica a lo generado. En esta obra se refiere a las ideas como constitutivas de un género de realidad que llama "la especie inmutable (Tò katà taútà عĩ̄os, Timeo 52a1), no generada e indestructible, que no admite nada en sí ni ella misma marcha a lugar alguno" (trad. de Lisi levemente alterada). Por tanto, no hay nada que objetar a la versión aristotélica de la teoría platónica de las ideas, cuando afirma que Platón propuso la existencia de entidades que no podían identificarse

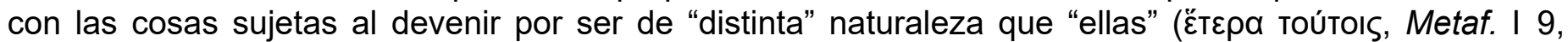
990b2, cf. 987b5). Esta heterogeneidad de las formas inteligibles, proclamada por el mismo Platón en el Fedón (74a11), es tan clara que está en la base del momento fundacional de la metafísica.

Sin embargo, cuando hablamos de transmundanidad no se trata solo de distinguir dos niveles de realidad, sino de separarlos y cosificarlos hasta el punto de imaginar una especie de dualismo constituido por dos estratos superpuestos entre los que no hay posibilidad de interacción, como si las entidades inteligibles habitaran en otro mundo. Como dijo Cherniss (1972: 211), la mala interpretación de Aristóteles no radicó "en la imputación a Platón del chōrismós en sí mismo sino en su concepción de las consecuencias necesarias envueltas en tal separación”. Esto es lo que le permite reírse despectivamente del platonismo cuando afirma que los platónicos procedieron, al establecer la teoría de las ideas, como alguien que "queriendo contar, pensara que no podía hacerlo por ser pocas las cosas" (trad. de T. Calvo, Metaf. I 9, 990b2-3). Es como si se hubiera duplicado inútilmente la realidad y ya no se viera después claramente el modo de relacionar los dos niveles distinguidos por la teoría. En realidad, "la filosofía primera" del propio Aristóteles, que él concibe en una de sus formulaciones como teología, es la que se acerca más a esto, ya que considera la metafísica como el estudio de una realidad trascendente que está más allá de las entidades físicamente constituidas. Su objeto son, en efecto, las sustancias eternas e inmóviles, desprovistas de materia y separadas de las cosas sensibles, que no tienen contacto alguno ni inmanencia directa en el mundo del devenir (cf. Metaf. XII 7, 1073a4). Pero la metafísica platónica no se constituye de esta manera, sino que nació como una "segunda navegación" (o deúteros ploûs, Fedón 99c9) cuya finalidad consistía en encontrar un sentido teleológico al devenir, ya que este había sido interpretado por los presocráticos como un orden ajeno a la intervención de causas teleológicas (sobre esta "segunda navegación", en la que radica el origen de la metafísica platónica, como interpretación teleológica del devenir, cfr. Vallejo 2021: 149-170). Cuando Platón recurre a la imagen del eclipse para

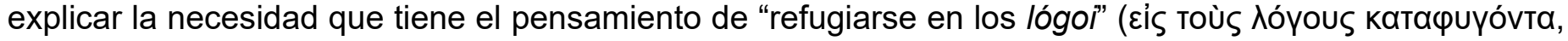
Fedón 99e5), para indagar en ellos la verdad de lo que es", nos advierte contra una interpretación literal de esta comparación, porque, según nos dice, no es cierto que quien contempla las cosas a la luz de los lógoi las vea más bien en imágenes que en su verdadera realidad. Esto es en lo que falla la comparación del eclipse: en este hay que renunciar a contemplar directamente la imagen del sol, porque puede cegarnos, y, por tanto, hay que observar indirectamente el fenómeno en una imagen atenuada. Pero esto no pasa con los lógoi, porque estos son proposiciones a través de las que contemplamos "las cosas que

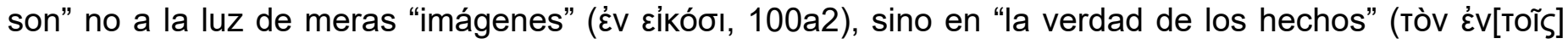
हैpyoıs, 100a2-3).

La metafísica platónica es una segunda navegación que va a la búsqueda de causas que expliquen el sentido que tiene el devenir y dicho sentido, como dice Sócrates en el Fedón, no puede venir del "aire, el éter, el agua o de otras muchas cosas absurdas" (98c1-c2), porque este tipo de causalidad puramente mecanicista aducida por los presocráticos es incapaz de explicar verdaderamente la forma de la que están dotadas las realidades naturales. A juicio de Platón, si la causa del devenir es el Noûs propuesto 
por Anaxágoras, la inteligencia no puede haber producido otro orden ni haber conferido a las cosas otra

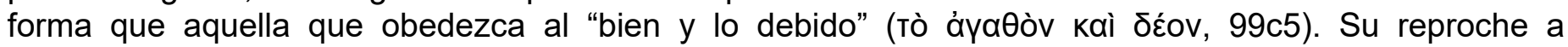
Anaxágoras, basado en el optimismo metafísico que Nietzsche critica tan a menudo en Platón, es que propuso una inteligencia como causa del movimiento $\mathrm{y}$, sin embargo, el Noûs no interviene teleológicamente ni se indica en qué medida el orden obedece al designio inteligente de una mente que busca el bien. La metafísica, que es en lo que consiste la segunda navegación, tiene como objeto el

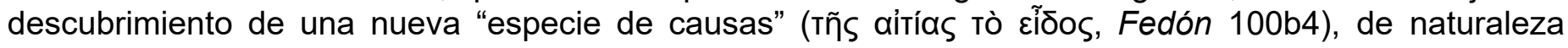
inteligible, como "lo bueno" y "lo bello" (Fedón 100b), que son las únicas que pueden dar un sentido al devenir natural. La misión de los lógoi, que representan el aspecto epistemológico de esta metafísica, no consiste en otra cosa más que en interpretar la realidad natural a la luz de estos principios que iluminan el sentido teleológico que le ha sido conferido por la inteligencia. Por supuesto, esto no es una mera física, como la que pretendían establecer los presocráticos, sino toda una metafísica, que estriba en interpretar el devenir natural a la luz de principios inteligibles. No hay aquí, sin embargo, como puede comprobarse, transmundanidad: la vocación de Platón no tenía nada que ver con inventar un mundo paralelo, alejado del mundo en que vivimos, para refugiarse en él, sino en proponer una serie de conceptos a la luz de los cuales pudiera comprenderse mejor el devenir natural, al comprobar la inmanencia en él de principios que trascienden la mera apariencia física de las cosas. Como dijo una vez Ortega (1965: 156-157), comentando veladamente este pasaje, en Platón la referencia a "un lugar supraceleste" está motivada por "ver qué se puede decir con sentido sobre las cosas de este mundo que tanto carecen de él" y, por tanto, lo suyo era "una fuga para acercarse", "la invención más genial que en el orden teorético se ha hecho en el planeta", porque "la ciencia moderna es platonismo en marcha". Permítame el lector en una traslación ajena al platonismo que ponga como ejemplo el caso de la gravitación, que es un concepto newtoniano al que se llegó después de un esfuerzo denodado por comprender el sentido de los movimientos planetarios. Pero nos sirve como ejemplo para comprender esta extraña simbiosis de inmanencia y trascendencia que el platonismo nos propone, ya que la gravitación es una realidad presente en las cosas que nos rodean y a la vez trascendente, porque regula una inmensidad de cosas que no puede ser abarcada con la mirada puramente sensible que produce "la ceguera del alma" (Fedón 99e) a la que Platón se refiere en estos pasajes. Frente al "sensualismo aristotélico", Ortega (1965: 157, nota 1) reconoce la fisonomía radicalmente paradójica del método platónico, como es propia de "toda grande filosofía", que se impone a sus muchos "errores y defectos". Pero no hay aquí transmundanidad, sino un intento de recurrir a realidades como el bien y la belleza con las que se trata de dar un sentido al mundo que nos rodea.

\section{La transmundanidad del pensamiento platónico: inmanencia y trascendencia}

Lo que acabamos de decir no es obstáculo para reconocer los problemas teóricos del platonismo, sino que se refiere exclusivamente al error de interpretar la metafísica platónica como un dualismo grosero de cosas separadas al estilo aristotélico, ya que lo característico de Platón es esa combinación de inmanencia y trascendencia. Pero esto es muy a menudo olvidado o minusvalorado de una manera que borraría las sutiles diferencias con "el platonismo para el pueblo" al que nos venimos refiriendo. Lo que hemos dicho vale para descartar, como dice Reale (1995a: 195), "el ridículo dualismo de quien hipostasia las abstracciones y después contrapone la hipóstasis a lo sensible mismo". Pero esto no debe tampoco ocultar los problemas. En los diálogos, Platón describe las ideas con un vocabulario técnico o cuasi técnico que subraya la heterogeneidad de la forma frente a las cosas en las que se encarna. Por ejemplo, en los pasajes del Fedón donde por primera vez se habla de la metafísica de las formas, se dice que la forma de lo igual no es la igualdad que hay entre leños y piedras iguales, sino "algo diferente

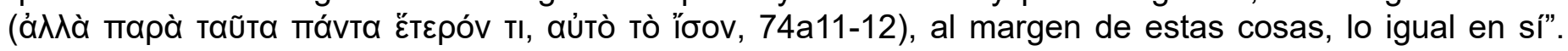
Esta heterogeneidad en la que se basa "la separación" que Aristóteles le atribuye es descrita por Platón como una realidad que es "en sí misma" (aútò kaق' aùtò, Fedón 78d5-6; Banquete 211b1), a diferencia de la igualdad o la belleza que se dan en las cosas. Dejando de lado otras características no menos importantes, como su inmutabilidad, frente al carácter cambiante de la igualdad o la belleza que observamos en las cosas (cfr. Fedón 78d, Banquete 211b), fijémonos en su carácter monoeidético

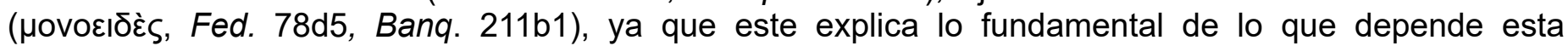
diferencia. Las cosas que percibimos por los sentidos constituyen una amalgama de cualidades que se mezclan con sus contrarias y así, lo igual en los leños, la belleza en los rostros o la justicia en la polis nunca alcanzan la perfección de aquello que es en sí lo que es y no admite nada contrario a su esencia. Esto es lo que significa la cualidad distintiva del ser ideal: su naturaleza monoeidética es la condición óntica de la perfección axiológica propia de todas las formas. 
La teoría de las ideas es una concepción normativa del ser que contempla las cosas no simplemente como son, sino como deberían ser para alcanzar una perfección que solo puede aprehenderse por medio de la inteligencia. Por eso dijo Kant (1993: 310) con razón que para Platón "nunca se halla en la experiencia algo que concuerde con una idea". Renunciar a estas entidades esenciales puras, que, por tanto, son diferentes de las cosas en las que aparecen encarnadas equivaldría a dejar al pensamiento sin la base objetiva que le permite impugnar lo existente, pues a Platón no le basta la mera existencia de las cosas por el mero hecho de existir como justificación ontológica.

Platón, al intentar poner todo el énfasis en la necesidad de esta doble perspectiva que se da entre la existencia fáctica y la exigencia ideal, se acerca muchas veces a esa "separación" que Aristóteles atribuye a las ideas, aunque el Estagirita subraye una de las dos aristas que simplifica el problema en la forma de un dualismo improductivo. Podríamos citar el caso de lo bello en sí, esa Belleza divina (aủtò tò

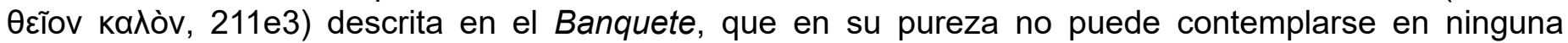

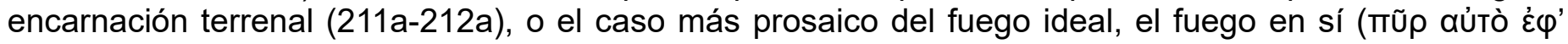
غ̇autoũ, Timeo 51b8), que nos sirve para enjuiciar la condición mixta del fuego que arde en la realidad sensible que nos rodea. Desde el punto de vista de esta ontología normativa Platón se niega a conceder

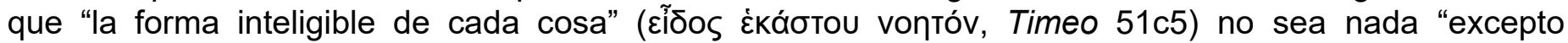

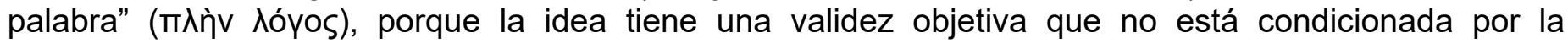
existencia de las cosas que se ubican en el espacio y el tiempo. Quizás el caso más sorprendente en el que Platón mantiene la legitimidad de esta perspectiva dual es el de la astronomía, pero, bien interpretado, resulta muy iluminador. En la República Sócrates contempla dos clases de astronomía, pues, además de la disciplina empírica que se dedica a registrar meramente los movimientos observados en los astros, hay otra "astronomía verdadera" que debe "abandonar el cielo estrellado" (530b7). Una vez más estamos ante el movimiento teórico que Ortega llama "la fuga para acercarse". Este es un caso extremadamente paradójico, que se presta a la simplificación característica de Aristóteles en el sentido que venimos explicando. Para el Estagirita esta astronomía verdadera nos llevaría a una duplicidad que obligaría a suponer "un Firmamento además del firmamento sensible y un Sol y una Luna y lo mismo con todo lo demás que hay en el firmamento" (Metaf. III 2, 997b16-18).

Pero Platón no tiene en mente un dualismo absurdo de entidades astronómicas, sino que parece referirse más bien a objetos ideales de otra naturaleza, que tienen que ver no con una duplicación absurda de los planetas, sino con números y figuras verdaderas (Rep. 529c), proporciones, esferas perfectas y leyes inalterables del movimiento (sobre la astronomía filosófica contemplada en el currículum de estudios previsto para el futuro filósofo gobernante, cfr. Vallejo 2018: 221-222). La astronomía filosófica tendría la tarea de reconstruir unas órbitas, que no son visibles con los ojos, sirviéndose de principios teóricos que marcaran su diferencia respecto a los movimientos aparentes de los astros. Como corroboración de lo que estamos diciendo, recordemos las noticias transmitidas por Simplicio (cfr. In De caelo VII. 488.22-23), según las cuales Platón propuso el problema de "salvar" o explicar los movimientos aparentes de los planetas "suponiendo como hipótesis movimientos regulares y ordenados", lo cual habría dado lugar al sistema de esferas concéntricas desarrollado por Eudoxo. Esta duplicidad entre lo observable y lo inteligible, que sobrepasa lo próximo para desentrañar su sentido, aunque unas veces se acierte y otras no, es lo que a Ortega (1965: 157) le parecía "la invención más genial que en el orden teorético se ha hecho en el planeta".

No obstante, hay que reconocer que el problema no es tan sencillo como el de la astronomía, porque otras veces no es solo una diferencia entre apariencia y realidad, sino entre dos niveles diferentes de perfección ontológica. Lo que Platón nos propuso era una ontología muy difícil de expresar en los términos de un pensamiento representativo y se comprende que, para popularizarse, tuviera que convertirse en el dualismo burdo de los dos mundos al que se refiere Nietzsche con su expresión del "platonismo para el pueblo". Esto no quiere decir en mi opinión que Platón tuviera una teoría de las ideas coherente y acabada, sino que pretendía ubicarse en un plano extremadamente sutil que combinaba la trascendencia y la inmanencia. Aunque D. Ross, el gran comentarista de Aristóteles, dé la razón a este en su interpretación del carácter separado que atribuye a las ideas, las conclusiones a las que llega sobre la teoría de las ideas en Platón muestran la forma oscilante en que la doctrina fluctúa entre expresiones que subrayan la inmanencia y otras que insisten en la trascendencia (cfr. Ross 1989: 269 y ss.; respecto a la separación que Aristóteles le atribuye, véase, por ejemplo, la página 274). Las dos, recordémoslo, son necesarias para la teoría: la inmanencia lo es, porque esta doctrina se propone para esclarecer la verdad de las cosas, que los presocráticos no pudieron desentrañar desde un punto de vista meramente naturalista, pero también lo es la trascendencia, que es imprescindible para mostrar la distancia de la realidad fáctica frente al ideal. Algunos comentaristas, para salvar esta ambigüedad que 
podría interpretarse como una contradicción de la teoría, han llegado a introducir una distinción entre "las formas y los caracteres inmanentes" (Devereux 2003: 213). Esta propuesta, presentada por Devereux, disiparía la ambigüedad, ya que las formas serían separadas de los particulares y los supuestos "caracteres inmanentes" evitarían el abandono de la inmanencia, que haría inútil la teoría. El problema es si esa distinción, como otras muchas ensayadas por sus intérpretes, ha sido realizada por el mismo Platón, pues no tiene una base textual que la avale terminantemente. Además esta solución, a mi juicio, lo que hace es posponer el problema a otro nivel, porque entonces habría que replantear qué relación tienen las ideas con los caracteres inmanentes que a su vez están en las cosas. (Para apoyar su propuesta, Devereux sostuvo que Platón reserva en el Fedón el término idéa para los caracteres inmanentes; véase una crítica de esta propuesta en González 2002: 72, nota 55).

El Parménides es un diálogo muy discutido, en cuyos secretos no podemos entrar ahora, pero vamos a mencionar un par de cuestiones que vienen a recordarnos la necesidad que tenía Platón de mantener ambos aspectos en su concepción de las formas. Por un lado, está la separación. Parménides se dirige a un joven e inexperto Sócrates que Platón presenta así en este diálogo para disipar malentendidos de su teoría. A juicio de Parménides "la mayor dificultad" (Parm. 133b) que tendría que afrontar esta doctrina se derivaría de proponer la existencia de las formas como entidades que "son en sí y por sí" (óvta aútà kaق'

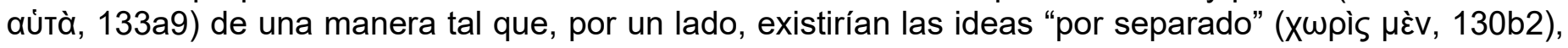
y por otro lado, "también separadamente" ( $\chi \omega$ pì $\delta \grave{~}$ ), "las cosas que participan de ellas". Recordemos de paso que es Parménides y no el joven Sócrates el que insiste en el lenguaje de la separación. Si la teoría se defendiera de esta manera, como alguien podría haberla interpretado, en la forma de un dualismo de entidades que existen en planos ontológicos separados, ni siquiera "podrían ser conocidas" (133b5), con lo cual quedaría imposibilitado uno de sus objetivos fundamentales, que consistía en proporcionar un fundamento permanente y objetivo al conocimiento. Pero, por otro lado, si se interpretara la participación de las cosas en las ideas como la inmanencia de una cosa material en otra, entonces la teoría se vería envuelta en dificultades insuperables, ya que la idea perdería su unidad al verse dividida en la multitud de cosas en la que tendría que estar presente por su propia espacialidad (puede verse un resumen de esta y otras aporías de la participación en Vallejo 2017: 218-224). El Parménides presenta muchas dificultades que no han recabado la unanimidad de los especialistas, pero hay dos cosas claras respecto al tema que venimos tratando. La primera es que, a pesar de las dificultades, no se puede renunciar a las ideas, porque si no, como dice Parménides en la obra, "no tendríamos adonde dirigir el pensamiento" (135b8) y "se destruiría por completo la facultad dialéctica" (trad. de M-I. Santa Cruz). Pero, en segundo lugar, para cumplir sus funciones, la teoría tiene que renunciar no solo a la trascendencia propia de las hipóstasis que están en dos mundos separados sino también a la inmanencia concebida materialmente como la inserción de una cosa en otra cosa de su misma naturaleza.

En resumen, si separamos las formas en los términos de la duplicidad que Aristóteles critica en el Libro I 9 de la Metafísica, se convierten en inútiles para explicar, como él dice, el movimiento, el ser y el conocimiento verdadero de las cosas (cf. 991a8-991a14). Pero si les atribuimos la existencia de las entidades materiales ubicadas en el espacio y el tiempo y las hacemos inmanentes en las cosas que participan de ellas, la teoría se destruye en una multitud de aporías insuperables. El Parménides se escribió para disipar ambos malentendidos (2). Esto no significa que Aristóteles haya hecho algo tan simple como fabricar un enemigo para criticarlo mejor, sino que el propio Platón probablemente no acertó con una fórmula clara que pudiera evitar "las metáforas poéticas" a las que se refiere Aristóteles tan despectivamente cuando pasa revista a los intentos platónicos de poner en relación los dos planos de la realidad que había distinguido. Aunque la fórmula, ensayada en el Timeo, de la conversión de la idea en un modelo de la creación, por un lado, y las figuras mediadoras del Demiurgo y el espacio, por otro lado, hayan representado un último intento de mantener vivas ambas aspiraciones, no es extraño que Platón haya tenido que recurrir a metáforas y símiles para expresar lo que a veces parece más un deseo y una aspiración utópica que la descripción de un continente verdaderamente descubierto con sus mapas y el detalle de su constitución ontológica. De ahí que no puede sorprendernos la actitud de aquellos que han llegado incluso a negar que exista verdaderamente una teoría platónica de las ideas (므). Pero vamos por último a comentar un par de metáforas que nos explican el sentido del dualismo que se convirtió en platonismo para el pueblo.

\section{“Palabras vacías y metáforas poéticas” (Metafísica, I 9, 991a21-22)}

Dado este estatuto ontológicamente ambiguo de las ideas y las dificultades de la teoría para explicar los 
mecanismos de la participación, no es difícil comprender por qué Platón ha dicho en realidad tan poco de las ideas y por qué ha tenido que recurrir a metáforas y símiles para transmitir una doctrina que no se deja comunicar fácilmente. En la Carta VII, donde el autor explica los motivos por los que no habrá nunca una obra que describa abiertamente su metafísica, nos dice que se trata de cuestiones que "no es posible expresar en forma alguna, como ocurre con otras enseñanzas, sino que, gracias a una continua familiaridad con el asunto y a la convivencia con este, de repente, como brota una chispa, se enciende una luz en el alma y ya se alimenta por sí misma" (Carta VII 341c4-d2). Heidegger dijo una vez, cuando no había declarado aún su guerra abierta contra el platonismo, que no se puede "preguntar por la idea del Bien... como cuando preguntamos cuál es el camino más próximo para la plaza del mercado" (Heidegger 2007: 98). Hay un elemento indecible en el pensamiento platónico que no se deja expresar como los demás conocimientos, tal vez porque escape al pensamiento representativo y lo más que podemos alcanzar, como dice Heidegger, es llegar con el rigor del preguntar "a la cercanía de lo indecible" (Heidegger 2007: 99). De ahí el uso de esas "metáforas poéticas" que a Aristóteles parecían "palabras vacías" que no aciertan a describir de forma clara y terminante lo que hay que expresar. No es una casualidad que Platón haya creado algunos de los símiles e imágenes más famosos de la historia de la filosofía. La alegoría de la caverna expresa, como ha dicho Reale (1995b: 353), "todo Platón" y debemos atender aquí al modo en que se combinan las imágenes para expresar la esencia más importante de su pensamiento.

Lo más fácil en una interpretación estática del símil es ver el mundo subterráneo de la caverna como una representación del mundo sensible y el espacio exterior como un ámbito separado, cada uno con sus propios objetos, como si constituyeran una duplicidad de entidades, unas dentro y otras fuera de la caverna. Las cosas que hay en el mundo subterráneo son imágenes de otras verdaderas, pero la trascendencia aquí significa que no podemos dar por buena la existencia fáctica de las cosas. La justicia en la polis es una sombra o una imagen devaluada de lo que debería ser si atendemos a la esencia normativa de la idea que se ve en ella débilmente reflejada. En este sentido está en ella, que la representa desfiguradamente, pero también más allá, porque no puede identificarse con su encarnación terrena. El prisionero liberado de sus cadenas puede salir al "exterior" con la potencia iluminadora del conocimiento: no está recluido en un mundo separado. El punto a mi juicio más decisivo de esta imagen no es el dualismo extático de la separación, sugerido por la representación iconográfica, sino el elemento dinámico que exige al prisionero volver a "bajar" al mundo subterráneo para liberar a sus antiguos compañeros de esclavitud (sobre el elemento estático y dinámico de la alegoría, cfr. Vegetti 2012: 192-3 y 2003: 23; una interpretación pormenorizada de la alegoría, puede verse en Vallejo 2018: 203-213). En este sentido, "no existen en realidad dos mundos", como dice Vegetti (2012: 193), sino que "hay un solo mundo", que es lo que hace posible los tránsitos o, dicho en el lenguaje iconográfico de la alegoría, el ascenso y el descenso. El filósofo debe ser educado para lograr el "ascenso" (Rep.519d1), que consiste en el conocimiento de ideales basados en una ontología normativa que no está condicionada por la existencia empírica de las cosas. Pero luego debe "bajar" (Rep. 520c1) al mundo subterráneo para iluminar con su conocimiento de "lo bello, lo justo y lo bueno" (520c5-6) la existencia de las sombras en la que transcurre la vida de sus antiguos compañeros. Los comentaristas han observado muy justamente

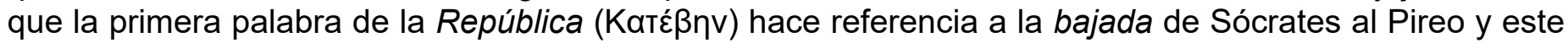
descenso es premonitorio del mensaje fundamental de la obra. No estamos, pues, ante dos mundos separados, sino ante dos niveles de realidad y no solo se puede, sino que se debe bajar de uno al otro, porque "liberación y ascensión no significan un desplazamiento en el espacio, sino una conversión de la mirada intelectual" (Vegetti 2012: 193).

El Fedón es un diálogo determinado por la escena dramática en la que transcurre su acción, ya que los discípulos se han reunido para acompañar a Sócrates en el momento de su muerte. No es extraño, pues, que se extremen aquí las expresiones dualistas y la filosofía aparezca como un "ejercicio de la muerte" (67e5), que consiste en dejar a solas el alma, para que no se vea contaminada por el poder ilusorio de lo sensible. También hay muestras de este escapismo cuando Platón tiene presente las dificultades que se oponen a la existencia filosófica, extraña a las insidias de la polis y al ambiente de las luchas políticas que hacen imposible el ejercicio de la razón en la esfera pública. "Como los males están ligados a la naturaleza mortal", lo deseable es huir "de este mundo de aquí... hacia allá con la mayor celeridad", pero "la huida consiste", observemos el doble lenguaje, "en hacerse uno tan semejante como sea posible a la divinidad, semejanza que se alcanza por medio de la inteligencia con la justicia y la piedad" (Teeteto 176a7-b3). Sin embargo, frente a la tentación de la fuga, motivada por la frustración del filósofo ante los males de la patria, el mensaje de la República es claro: hay que acceder al mundo exterior con la finalidad de volver a este y liberar a los que viven aquí, obnubilados por un mundo de sombras e 
ilusiones. Esta es la tarea principal que Platón encomienda al filósofo y no hay en ello ninguna transmundanidad.

Cuando Nietzsche contrapone al platonismo de la primera fase la recepción de la idea del mundo verdadero en el cristianismo, deja bien claro este contraste: en el platonismo el sabio (o el piadoso y el virtuoso) "vive en ese mundo", mientras que el cristianismo lo convierte en un mundo inalcanzable o "inasequible por ahora" (unerreichbar für jetzt), que solo puede ser "prometido" (versprochen) para una próxima existencia transmundana. Nietzsche comprendió que el dualismo platónico del mundo verdadero no podía identificarse con la transmundanidad característica del cristianismo, aunque a su juicio la idea del mundo verdadero se volvía así "más sutil y capciosa".

Hemos recordado las críticas simplificadoras de Aristóteles, que ha intentado a veces en su interpretación de la heterogeneidad ontológica una concepción "localista" de las entidades ideales. Lo que debemos preguntarnos es si es posible representarse una existencia, como la de las ideas, fuera del espacio y del tiempo y, por tanto, ajena a muchas dificultades propias de las que surgen cuando queremos pensar su ser con las categorías propias de nuestra experiencia humana. De aquí nacen probablemente todas las dificultades y aporías insuperables de la teoría. En el Fedro Platón vuelve a recurrir, una vez más, como no podía ser de otra manera, a una representación iconográfica del mundo inteligible que tiene que valerse de una localización en el espacio. Nos habla de "un lugar supraceleste"

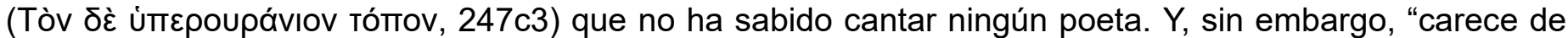
color y de forma y es impalpable" y "solo puede ser contemplada por el piloto del alma", de manera que en la misma línea en la que nos sugiere una metáfora que traslada a un espacio mítico "la verdadera

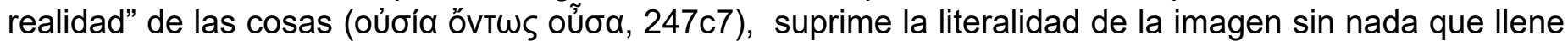
ese hueco que las representaciones propias del entendimiento humano desearían cumplimentar con una clara descripción conceptual. En balde la buscaremos en Platón. Se trata de una realidad que es causa de las que nos rodean, como dice el Fedón, y que de algún modo está en las cosas y a la vez más allá de ellas, porque, aunque explica la semejanza de las cosas entre sí que existen en las especies y los géneros, nunca halla en las cosas ninguna "imagen ( $\varepsilon i \delta \omega \lambda o v$, cfr. Fedro 286a1) claramente adaptada a los hombres" que se corresponda verdaderamente con su naturaleza esencial. Alguien podría pensar que no hay en realidad una teoría coherente sino una búsqueda permanente que intenta conciliar contrarios difícilmente compatibles, como la inmanencia que da sentido a la realidad y la trascendencia que intenta superarla, pero, desde luego, lo que tampoco hay es una ontología simple como es propia de la transmundanidad en la que se ha convirtió la fábula platónica del mundo verdadero.

\section{Notas}

1. A favor de que el propio Aristóteles fuera quien "acuñara la palabra" está Morrison (1985: 92). También se ha propuesto que el término existiera ya en la Academia y que Aristóteles lo tomara de ahí, ya que Jenócrates definió las ideas como "separadas y divinas" (frag. 94) (cfr. Vlastos 1992: 264).

2. Cfr. Kahn 2010: 362-363, quien afirma que "Platón era claramente consciente de los dos peligros" ( $p$. 363), es decir, de las dificultades en que incurriría la teoría si defiende tanto la inmanencia de las formas como una trascendencia que haría imposible incluso su conocimiento.

3. En este sentido F. González (2002: 31) habla de la existencia de una "dialéctica de las formas" más que de "una teoría sistemática sobre ellas". F. González (2002: 32-38) se refiere con cierta razón a la ingenuidad de muchos platonistas que han intentado las más diversas distinciones para salvar la coherencia de una teoría que el mismo Platón tal vez nunca tuvo clara.

\section{Bibliografía}


Cherniss, Harold

1972 Aristotle's criticism of Plato and the Academy. Nueva York, Russell and Russell.

Deleuze, Gilles

1971 Nietzsche y la Filosofía. Barcelona, Anagrama.

Devereux, Daniel T.

2003 "Separation and inmanence in Plato's theory of forms", en Gail Fine (ed.), Plato 1, Metaphysics and Epistemology. Oxford, Oxford University Press: 192-214.

Fink, Eugen

1979 La Filosofía de Nietzsche. Madrid, Alianza.

González, Francisco J.

2002 "Plato's dialectic of forms", en William A. Welton (ed.), Plato's Forms: Varieties of Interpretation. Lanham, Lexington Books: 32-83.

Heidegger, Martin

2007 De la esencia de la verdad. Madrid, Herder. Trad. de Alberto Ciria.

Kahn, Charles

2010 Platón y el diálogo socrático. El uso filosófico de una forma literaria. Madrid, Escolar y Mayo. Trad. de Alejandro García Mayo y prólogo de Beatriz Bossi.

Kant, I.

1993 Crítica de la Razón Pura. Madrid, Alfaguara. Trad. de Pedro Ribas.

Morrison, David

1985 “xwpıбтòv in Aristotle", Harvard Studies in Classical Philology, vol. 89: 89-105.

Nietzsche, Friedrich

1973 Crepúsculo de los ídolos. Madrid, Alianza. Trad. de Andrés Sánchez Pascual.

2006 Fragmentos póstumos, vol. IV. Madrid, Tecnos. Trad. de Juan Luis Vermal y Joan B. Llinares.

Ortega y Gasset, José

1965 La idea de principio en Leibniz, en Obras Completas de José Ortega y Gasset, vol. VII. Madrid, Revista de Occidente.

Reale, Giovanni

1995a Per una nuova Interpretazione di Platone. Milán, Vita e Pensiero.

1995b Storia della filosofía antica, vol. II, Platone e Aristotele, Milán, Vita e Pensiero.

Ross, David

1989 Teoría de las ideas de Platón. Madrid, Cátedra. Trad. de José Luis Díez Arias.

Vallejo, Álvaro

2018 Adonde nos lleve el logos. Para leer la República de Platón. Madrid, Trotta.

2021 "La interpretación de la naturaleza: metafísica y teleología. Nietzsche lector de Platón", Claridades, no 13-1: 149-170.

Vallejo, Álvaro (y Alejandro Vigo)

2017 Filósofos griegos: de los sofistas a Aristóteles. Pamplona, Eunsa.

Vegetti, Mario

2003 Platone. La Repubblica, vol. V, Libros VI-VII. Nápoles, Bibliopolis.

2012 Quince lecciones sobre Platón. Madrid, Gredos. Trad. de Miguel Salazar.

Vlastos, Gregory

1992 Socrates, Ironist and moral philosopher. Cambridge, Cambridge University Press.

Volpi, Franco

2004 II Nichilismo. Roma, Laterza. 
Welton, William A.

2002 “Introduction. Plato's Mysterious Forms”, en William A. Welton (ed.), Plato's Forms: Varieties of Interpretation. Lanham, Lexington Books: 1-29. 